Para enlazar con este artículo / To link to this article:

http://dx.doi.org/10.6035/MonTI.2019.ne4.5

Para citar este artículo / To cite this article:

BESEGHI, Micòl. (2019) "The representation and translation of identities in multilingual TV series: Jane The Virgin, a case in point." In: PÉREZ L. DE HerediA, María \& Irene Higes ANDino (eds.) 2019. Multilingüismo y representación de las identidades en textos audiovisuales / Multilingualism and representation of identities in audiovisual texts. MonTI Special Issue 4, pp. 145-172.

\title{
THE REPRESENTATION AND TRANSLATION OF IDENTITIES IN MULTILINGUAL TV SERIES: JANE THE VIRGIN, A CASE IN POINT
}

\author{
Micòl Beseghi \\ micol.beseghi@unipr.it \\ University of Parma
}

\begin{abstract}
This article discusses the complex relationship between multilingualism, translation and character portrayal in television series. In recent decades, cinema and TV have begun to include linguistic diversity in their productions in an attempt to pursue realism and to represent multilingual realities. TV series, which have become very popular with American and European audiences, increasingly display characters who speak more than one language or who use mixed language variants. Focusing on the TV series Jane the Virgin, this article explores the different forms and functions of multilingualism in the original version and analyses the translation strategies adopted in the Italian dubbed version, in order to verify whether multilingual discourse practices are maintained, adapted or neutralised and to consider the effects of such strategies on character portrayal.
\end{abstract}

\section{Riassunto}

Questo articolo analizza la complessa interrelazione tra multilinguismo, traduzione e caratterizzazione dei personaggi nel genere della serie televisiva. Recentemente, i prodotti cinematografici e televisivi hanno iniziato a includere le diversità linguistiche, nel tentativo di rappresentare fedelmente la realtà e i contesti multilingui. In effetti, le serie televisive, un genere molto popolare e apprezzato dal pubblico sia americano che europeo, mostrano sempre più personaggi multilingui. Focalizzandosi sulla serie TV Jane the Virgin, questo articolo esplora le diverse forme e funzioni del multilinguismo nel testo originale. Inoltre, l'analisi si concentra sulle strategie traduttive adottate nel doppiaggio italiano, al fine di verificare se le pratiche discorsive multilingui siano mantenute, adattate o neutralizzate e quali siano gli effetti di tali strategie sulla caratterizzazione dei personaggi. 
Keywords: AVT. Dubbing. TV series. Multilingualism. Characterisation.

Parole chiave: TAV. Doppiaggio. Serie televisive. Multilinguismo. Caratterizzazione. 


\section{Multilingualism on screen}

This article investigates the main issues involved in the process of translating multilingual TV series characterised by linguistic diversity, focusing on the complex relationship between multilingualism, translation and characterisation. In order to explore how multilingual TV series travel cross-culturally through audiovisual translation (AVT), the paper focuses on the Italian dubbing of a recent multilingual TV series, Jane the Virgin (CBS 2014- ). By analysing the original dialogues and their Italian dubbed version, translation strategies are investigated for those aspects concerning the multilingual phenomena that mark the characters' speech and shape their identity in sociocultural contexts. The descriptive analysis concentrates on the source text and on the target text - the Italian dubbed version - in order to observe the main issues in terms of linguistic diversity and transcultural transmission. Given the close relationship between linguistic and cultural issues in immigrant situations, the TV series Jane The Virgin seems particularly appropriate for a study of multilingualism, since it tells the story of a Hispanic immigrant family in the United States and portrays the lives of first-, second- and third-generation immigrants, who manifest their sociocultural identities through language among other means.

The growing presence of multilingualism in recent and contemporary American, British and European films is acknowledged by scholars in the field of Film Studies as well as AVT Studies. Indeed, in the last decades, films have increasingly included linguistic diversity, showing characters who speak languages "in the way they would be used in reality" (Wahl 2005). Kozloff (2000: 80) claims that films "display the pressure of polyglossia, of national languages jostling up against each other"; Bleichenbacher (2008: 21) considers films "as the most apt medium to represent the richness and complexity of real-life multilingual realities" and O'Sullivan (2011: 18) highlights the fact that multilingualism has become a vehicle for narration and characterisation. The increasing presence of multilingualism in films thus shows that the myth of a universal language is no longer pursued in cinema (Díaz-Cintas 2011). Indeed, most scholars agree that multilingual films aim at a more realistic rendering of the world's linguistic diversity, evolutions and mixes, thus moving away from 
the homogenised language use that was often associated with the language of cinema, particularly in Hollywood mainstream productions (Dwyer 2005; Parini 2015). This recent trend can be considered a sort of "multilingual turn" (Meylaerts 2006: 2), a "multilingual commitment" (O'Sullivan 2007: 84) which has the potential to promote the development of a "multilingual imagination" in the audience (O'Sullivan 2007: 81).

A growing number of theorists and scholars have proposed a definition of multilingualism that covers not only interlingual variants (i.e. official languages) but also intralingual ones, such as dialects, sociolects, different varieties of a language, foreign accents and even invented languages (Delabastita 2002, 2009; Corrius \& Zabalbeascoa 2011; Heiss 2004; Voellmer \& Zabalbeascoa 2014). This broader definition of fictional multilingualism, adopted in this study too, is reminiscent of Grutman's description (1996: 18) of heterolingualism as the coexistence in a text of foreign languages as well as social, regional or historical variations within the same language. Indeed, multilingualism on screen is a response to the global changes caused by phenomena such as mass immigration (Baldo 2009, 2010) and a result of directors and scriptwriters who wish to represent the linguistic diversity typical of contemporary society (Beseghi 2017; Bruti \& Di Giovanni 2012). The use of different languages or language varieties is also part of a new trend in filmmaking, reflecting an interest in representing the conditions of migrants and diasporic existence (Beseghi 2017; de Higes-Andino 2014; de Higes Andino et al. 2013; Wahl 2005). Since the way characters speak always reveals aspects of their personality, multilingualism is a fundamental aspect of character portrayal (i.e. the way characters are created and presented on screen), as underlined by Bleichenbacher (2008: 30) and Kozloff (2000: 43). In multilingual films, language may reveal attitudes towards identity, culture, ethnicity, age and gender, thus becoming the space of intercultural experience.

Although realism is found in multilingual films that aim at depicting language contact as closely as possible to real-life situations, multilingualism may also perform other functions. According to Bleichenbacher (2008: 26), multilingualism is associated with social criticism when language use is invested with ideological meanings, especially in films focusing on a clash or encounter between different cultures, where multilingualism becomes a strategy to represent linguistic and cultural diversity. As noted by de Higes Andino (2014) and Monti (2014), this is often the case in Ken Loach's social realist films. Furthermore, multilingual discourse is frequently associated with humour and is usually found in comedies where misunderstandings caused by the use of different languages produce comic effects (De Bonis 2014; 2015). 


\subsection{Multilingualism in TV series}

Although most AVT scholars have focused on the translation of multilingual films, on-screen multilingualism has become a widespread representational strategy in other audiovisual products such as TV series, nowadays a very popular genre thanks to dissemination on digital streaming platforms and DVD (Scaglioni 2006). In recent years, American TV series in particular have become extremely popular, and have garnered considerable critical attention from scholars of the audiovisual media, who have emphasised the significance of their narrative forms, their complex production and audience responses (Innocenti \& Pescatore 2014: 1).

In the past decade, an increasing number of American and British television series have displayed a range of different languages and language uses. Lost (ABC 2004-2010), one of the most popular TV series of all times, is a clear example of this recent phenomenon. Although the main language spoken in the original version of the show is English, different variants of this language, as well as entirely different languages, are used (i.e. Arabic, Chinese, French, German, Greek, Japanese, Korean, Italian, Latin, Portuguese, Russian, Spanish, Turkish), often accompanied by English subtitles. The science fiction TV drama Heroes (NBC 2006-2010) offers another significant instance of multilingualism and multilingual characters: besides English, other languages spoken are Arabic, French, German, Hebrew, Hindi, Japanese, Spanish, Russian, and Urdu, and there is Sign Language as well. The growing number of contemporary TV series where different languages are spoken appears to indicate that multilingualism is not related to a specific genre, channel or platform (TV or web). On the contrary, it is displayed in a wide range of shows, from fantasy drama (Game of Thrones, HBO 2011-), action and science fiction drama (Orphan Black, Space 2013-2017; Outlander, Starz 2014- ), mystery drama (Devious Maids, ABC 2013-2016), crime drama (Prison Break, 20th Century Fox 2005- ; Breaking Bad, AMC 2008-2013; Narcos, Netflix 2015- ), crime mystery drama (The Missing, BBC 2014-; Hinterland, BBC 2013-) to comedy drama (Orange is the New Black, Netflix 2013-; Jane the Virgin, CBS 2014- ) and comedy (Fresh Off the Boat, ABC 2015- ).

While most American TV series feature English as the main language alternating with one or more secondary language(s), there are also cases where different languages coexist without any actually prevailing. Narcos, for instance, can be considered truly bilingual, since English and Spanish are spoken to the same degree and neither of them seem to prevail. The decision to use a mixture of English and Spanish to tell the true story of the drug-trafficker Pablo Escobar was probably aimed at enhancing the authenticity of the 
show as well as attracting Spanish-speaking viewers. This may also explain the presence of Spanish in several American TV series (e.g. Breaking Bad, Devious Maids, Jane the Virgin, Prison Break).

\subsection{Translating multilingualism: challenges and issues}

The translation of multilingual audiovisual texts (films and TV series) poses a number of challenges and invites us to reconsider traditional dichotomies between source and target text, source and target language, dubbing and subtitling (Beseghi 2017). When a multilingual audiovisual text is translated for a different audience in another country, there is no single source language to be translated into a single target language. In order to deal with multilingual audiovisual texts and their translation, Corrius \& Zabalbeascoa (2011: 113) proposed the notion of a third language (L3) to refer to any other language(s) in the source text (L3ST) - where it coexists with the main source language (L1) - and in the target text (L3TT), where it coexists with the main target language (L2). The translation of multilingual films or TV series first of all involves the acknowledgment of the presence of L3. Corrius \& Zabalbeascoa (2011: 126) outline a range of possible operations acting on Ll and L3ST segments - deletion, repetition or substitution - which have different results in the translated text, including standardisation, change of function or connotation and L3 invisibility.

When a film is translated for the target country, a modality is chosen: the film for example can be dubbed or subtitled. Although Italy is traditionally a dubbing country (Parini 2009; Ranzato 2015), with the advent of the DVD, pay-per-view channels and digital/streaming platforms (e.g. Netflix) the audience can now choose not only what to watch and when, but also in which language, selecting their preferred AVT modality. In the case of multilingual films, even when dubbing is used as the main modality, lines in L3 may be left in the original version and subtitles may be used to translate such scenes. Possible strategies to deal with multilingualism are maintaining the original soundtrack and the presence, or absence, of subtitles. What is significant is not so much the modality used for the whole audiovisual text as the strategy chosen to deal with specific multilingual scenes. Indeed, one of the most important choices to be made when selecting a translation strategy, as de Higes Andino points out (2014: 222), is whether to mark multilingualism or not, in other words, whether to retain or erase the multilingual connotations of the original version. If the translator decides to mark multilingualism in the TT and L3 is present in the dubbed version, L3TT may be the same as, or different from, L3ST. Where it is the same, the original soundtrack is retained. When 
the dubbed version is characterised by the presence of L3, L3TT can either be translated - through part-subtitles ${ }^{1}$ or diegetic interpreting ${ }^{2}$ - or not translated at all. This strategy seems to be common when no subtitles are provided in the original version either (Bartoll 2006) or when the function of L3 in the ST is not essential for the comprehension of the scene.

\section{Jane the Virgin: translating a multilingual TV series}

This study illustrates the presence of L3 in the original and dubbed version of Jane the Virgin and analyses the different ways in which multilingualism is represented and how it contributes to constructing the characters' identity and connoting them socio-culturally. Jane the Virgin (JTV), an American comedy drama adapted from a Venezuelan telenovela, Juana la Virgen (RCTV 2002), was chosen for this investigation since it can be considered a multilingual TV series where language use and character portrayal are closely connected. The first two seasons of the show were taken into consideration for the descriptive analysis, for a total of forty-four episodes, all available on Netflix. ${ }^{3}$ The first phase of the analysis was aimed at identifying the segments of L3 in the original version, while the second phase focused on the translation strategies used to deal with multilingualism in the dubbed version. JTV was first broadcast by The CW Channel in October 2014. The first season was released in Italy in December 2015 on the streaming service Netflix, where viewers can select the AVT modality (dubbing or subtitling), and later aired on the state-owned channel Rai3, solely in the dubbed version. The second season was released on Netflix a year later.

The overall objective of the investigation is to answer the following questions:

1) Which translation strategies do translators use to deal with L3 segments in the dubbed version?

2) How does multilingualism contribute to character portrayal in the original and Italian dubbed versions?

1. Part-subtitles, also known as open subtitles, "are appended to part of the dialogue only, are planned from an early stage in the film's production, and are aimed at the film's primary language audience" (O'Sullivan 2007: 81).

2. Diegetic interpreting occurs when characters translate the foreign dialogue for other characters and thus for the audience.

3. The third season of JTV is not available in Italian at the time of writing. 
JTV revolves around the lives of a family of three different generations of Hispanic-American women: Jane Gloriana Villanueva, an ambitious twenty-three-year-old girl played by Gina Rodriguez, her mother Xiomara, a thirty-nine-year-old aspiring pop-star, and her grandmother Alba, who is very religious and old-fashioned. JTV has received much critical acclaim, both for the significance of its universal themes, such as immigration, citizenship, deportation, abortion, and for the protagonist's performance ${ }^{4}$. By subverting what is typically expected of the telenovela format, JTV combines melodramatic elements with surrealism and explores the nature of storytelling itself, since the protagonist is an aspiring novelist who engages with different genres. JTV is in fact divided into chapters, rather than episodes, thus recreating on screen the structure of a novel. Its narrative complexity is also realised through language, from the frequent use of on-screen text to the alternation of different languages. The show portrays multi-dimensional, complex characters who are not stereotypical or standardised representations of Latinos in America (e.g. Hispanic housemaids). Gina Rodriguez, herself a second-generation Puerto Rican immigrant raised in Chicago, described JTV as the "most authentic, genuine representation" of a Hispanic family she had ever seen on TV: "For once, I was reading a script where they weren't talking about my ethnicity. They weren't putting a Puerto Rican flag on my shoulder. They weren't putting a taco in my hand." 5

The series tells the story of Jane, who wants to remain a virgin until marriage, but finds herself artificially inseminated, by mistake, with her boss's child. Jane lives in Miami with her mother Xiomara, who is following her dream of becoming a famous singer, and her grandmother Alba, now a widow, who emigrated with her husband from Venezuela to the United States. JTV showcases a realistic portrayal of a matriarchal, multi-cultural and multi-generational household where more than one language is spoken (i.e. English and Spanish). Furthermore, it capitalises on questions of cultural and linguistic identity in the multi-ethnic city of Miami: Alba is a first-generation Hispanic immigrant who speaks Spanish most of the time and is devoted to religion and Latino cultural values. Xiomara and Jane are respectively second- and third-generation immigrants who mostly speak English but occasionally use code-switching and code-mixing with Spanish.

4. Gina Rodriguez in fact won the award for Best Actress in a Television Series, Musical or Comedy at the $72^{\text {nd }}$ Golden Globe Awards in 2016.

5. Itkzoff, D. "Jane the Virgin Aims Beyond Its Latin Ethnicity" The New York Times (19 September 2014). Online version: <https://www.nytimes.com/2014/09/21/arts/television/ jane-the-virgin-aims-beyond-its-latin-ethnicity.html> 
The show contains a significant amount of dialogue in Spanish, which is often subtitled in English, sometimes interpreted diegetically by bilingual characters or translated by the narrator via voiceover, but in some instances is left untranslated. Although JTV portrays a Spanglish household, and shows code-switching and code-mixing in the characters' daily lives, Spanish is not the only L3. There are also entire dialogues, isolated sentences and words in Czech, German, French and Italian.

The Italian dubbed version is characterised by the presence of L3: lines in L1 (English) are dubbed into L2 (Italian), while L3 exchanges are kept in the original version ( $\mathrm{L} 3 \mathrm{ST}=\mathrm{L} 3 \mathrm{TT})$. However, it should be noted that only the first season provides part-subtitles in Italian for the exchanges in L3TT, while the second season does not seem to follow a coherent strategy, since part-subtitles are available only for certain episodes ${ }^{6}$. As a consequence, viewers who do not understand L3 may need to activate subtitles which will unavoidably appear for all the spoken lines (L2 and L3).

The following sections illustrate the ways in which L3 is manifested in the original and dubbed versions of the show, through a selection of examples from the first two seasons, focusing on the translation solutions and their impact on character portrayal.

\subsection{Code-switching and code-mixing in the original and Italian dubbed version of Jane the Virgin}

JTV portrays a multilingual family where each character builds his or her own linguistic identity and where multilingualism characterises the interactions between family members. When a multilingual community is represented on screen, code-switching and code-mixing are two fundamental discourse strategies used to express a character's affiliation to a specific culture, where the choice of code can be socio-culturally or emotionally symbolic (Beseghi 2011; Monti 2014; 2016). Code-switching indicates the switch from one language to another either across turns (turn-specific code-switching) or between sentences (intersentential code-switching, Myers-Scotton 1997). Code-mixing, or intrasentential code-switching, indicates switches occurring within the same sentence or clause (ibid.). In terms of functions, code-switching can be situational, in which case the switch is determined by a specific social or cultural situation, and the language used changes accordingly (Wardhaugh 2002: 103).

6. The Italian version of the second season, available on Netflix, inexplicably presents an incongruity, since part-subtitles are present only in Episodes 1, 6, 9, 10, 11, 15, 16, 18, 20 and 21 , and are absent in all the other episodes. 
Otherwise, code-switching can be metaphorical, in which case the switch has an "affective dimension" (ibid.): the language used draws attention to itself and communicates metaphorical information beyond denotative meaning (Gumperz 1982: 61).

First-generation immigrants frequently switch from the majority language, or "they-code", to the minority language, or "we-code" (ibid.: 95), as a means to express sociocultural values and a sense of belonging to a social or ethnic group. Second-generation immigrants, on the other hand, tend to choose the majority language to communicate. This multilingual phenomenon is represented on screen in JTV: Alba, a first-generation immigrant, has remained closely tied to her Latino origins. From a linguistic point of view, although she has been living in the United States for over forty years, she prefers to use the Spanish language, the we-code, in almost all her interactions, thus expressing her attachment to her cultural heritage. By avoiding English, the they-code, Alba tries to resist the linguistic and cultural pressure of the host society in order to maintain her identity, especially, but not exclusively, in the family domain. On the other hand, Jane and Xiomara, who understand Spanish perfectly, always communicate in English. Spanish-English code-switching permeates most of the conversations between the members of the Villanueva family. Code-switching in most cases is turn-specific, since each character uses a different language in the exchange. Example $1^{7}$ shows one of the many multilingual conversations between Alba, Jane and Xiomara, in which Alba addresses her granddaughter and daughter in Spanish (L3ST) and they answer her in English (L1). In the original version, the meaning of L3 lines is conveyed through part-subtitles in English. The same strategy is used in the Italian dubbed version, where Alba's original voice is left unchanged and subtitles in L2 are added.

7. When L3 is subtitled in the original version and/or in the dubbed version, part-subtitles are reported in between square brackets. If L3 is not subtitled, the transcript simply reports the original lines. Lines in L2 are accompanied by a back translation into English between parenthesis. The / symbol indicates a new subtitle. 
Example 1. Chapter 1 (season 1, episode 1, 00.26)

\begin{tabular}{|c|c|}
\hline $\begin{array}{l}\text { ORIGINAL VERSION } \\
\text { [part-subtitles] }\end{array}$ & $\begin{array}{l}\text { ITALIAN DUBBING (back translation) } \\
\text { [part-subtitles] }\end{array}$ \\
\hline $\begin{array}{l}\text { Alba: Mira la flor que tienes en tu mano } \\
\text { Jane. Mira qué tan perfecta es. Qué tan } \\
\text { pura. Ahora, mi hija, estrújala en tus } \\
\text { manos. } \\
\text { [Look at the flower } \\
\text { in your hand, Jane./ } \\
\text { Notice how perfect it is./ } \\
\text { How pure./ } \\
\text { Now, mija,/ } \\
\text { crumple it up.] } \\
\text { Xiomara: Really mom? But this is so lame! } \\
\text { Jane: Mommy, ssh! } \\
\text { Alba: Estruja la flor Jane. Bien. Ahora haz } \\
\text { que se vea como nueva otra vez. Vamos, } \\
\text { anda, trata. } \\
\text { [Crumple the flower, Jane./ } \\
\text { Now try to make it } \\
\text { look new again./ } \\
\text { Go on.] } \\
\text { Jane: I can't. } \\
\text { Alba: Así es. Nunca puede volver atrás. } \\
\text { Y eso es lo que sucede cuando pierdes } \\
\text { tu virginidad. Nunca puede volver atrás. } \\
\text { Nunca olvide eso, Jane. } \\
\text { [That's right. } \\
\text { You can never go back./ } \\
\text { And that's what happens } \\
\text { when you lose your VIRGINITY./ } \\
\text { You can never go back./ } \\
\text { Never forget that, Jane.] }\end{array}$ & $\begin{array}{l}\text { Alba: Mira la flor que tienes en tu mano } \\
\text { Jane. Mira qué tan perfecta es. Qué tan } \\
\text { pura. Ahora, mi hija, estrújala en tus } \\
\text { manos. } \\
\text { [Guarda il fiore } \\
\text { che hai in mano, Jane./ } \\
\text { Nota la sua perfezione./ } \\
\text { Quanto è puro./ } \\
\text { Ora, piccola mia,/ } \\
\text { sciupalo.] } \\
\text { Xiomara: Sul serio mamma? Ma è } \\
\text { un'idiozia! (Really mom? But this is } \\
\text { nonsense!) } \\
\text { Jane: Mamma, ssh! (Mommy, ssh!) } \\
\text { Alba: Estruja la flor Jane. Bien. Ahora haz } \\
\text { que se vea como nueva otra vez. Vamos, } \\
\text { anda, trata. } \\
\text { [Sciupa il fiore, Jane./ } \\
\text { Ora prova a farlo sembrare nuovo./ } \\
\text { Continua.] } \\
\text { Jane: Non riesco. (I can't.) } \\
\text { Alba: Así es. Nunca puede volver atrás. } \\
\text { Y eso es lo que sucede cuando pierdes } \\
\text { tu virginidad. Nunca puede volver atrás. } \\
\text { Nunca olvide eso, Jane. } \\
\text { [Esatto. } \\
\text { Non puoi tornare indietro./ } \\
\text { Ed è ciò che succede } \\
\text { quando perdi la VERGINITÀ./ } \\
\text { Non puoi tornare indietro./ } \\
\text { Ricordalo sempre, Jane.] }\end{array}$ \\
\hline
\end{tabular}

There are only two occasions when Alba speaks English in the first two seasons. One is when she decides to apply for her Green Card and become a U.S. citizen, after living in the country illegally for over forty years. When she goes to meet her immigration lawyer, she introduces herself in English, therefore expressing her wish to be part of American society (Example 2). While in the original version, Alba speaks English correctly, but with a Spanish accent, in the dubbed version she speaks Italian more hesitatingly and with a more marked Spanish accent. Furthermore, she uses code-mixing, inserting a Spanish preposition (de) in her utterance. In this case, it seems that dubbing professionals opted for a strategy of hypercharacterisation, by which the speech of a character is more marked phonologically, morpho-syntactically or lexically (Parini 2009: 161). 
Alba's speech in Italian is more marked from a phonological point of view and presents non-standard morpho-syntactic features deriving from the influence of Spanish (i.e. code-mixing). This results in a possible misrepresentation of the character's identity: Alba's insecurity in Italian may indicate that her choice to always speak Spanish is dictated by purely linguistic reasons - her poor knowledge of the they-code - rather than sociocultural ones.

Example 2. Chapter 27 (season 2, episode 5, 10.12)

\begin{tabular}{|l|l|}
\hline \multicolumn{1}{|c|}{ ORIGINAL VERSION } & \multicolumn{1}{c|}{ ITALIAN DUBBING (back translation) } \\
\hline $\begin{array}{l}\text { Alba: Alba Villanueva, nice } \\
\text { to meet you, and I'm looking } \\
\text { forward to becoming a citizen } \\
\text { and to visiting Helena, the } \\
\text { capital of Montana. }\end{array}$ & $\begin{array}{l}\text { Alba: Alba Villanueva, piacere mio. Non vedo l'ora } \\
\text { di... di ottener la cittadinanza e de visitare Helena, } \\
\text { la capitale del Montana. } \\
\text { (Alba Villanueva, nice to meet you. I'm looking } \\
\text { forward to... to becoming a citizen and de visiting } \\
\text { Helena, the capital of Montana.) }\end{array}$ \\
\hline
\end{tabular}

The other occasion when Alba speaks English is with her friend Edward: their dialogues are an example of non-reciprocal language use, since Alba speaks Spanish and Edward speaks English. Alba utters a line in Ll only once, when she explains to him that they cannot be more than friends ("If this did not happen I would not have my new friend", Chapter 20, Season 1, Episode 20). The use of code-switching is clearly symbolic in this case, since Alba is expressing her feelings and does not want to hurt Edward, who is in love with her, so she uses the English language to bridge the gap between them. The Italian dubbed version substitutes L1 with L2 and overemphasises her Spanish accent in Italian. Another situation in which Alba uses English is when she sings. These scenes are not real but imagined by Jane, who often daydreams and sees members of her family in sorts of "musical hallucinations". Somewhat surprisingly, the Italian dubbed version leaves the songs unchanged $(\mathrm{Ll}=$ L3TT), without subtitles, which may be problematic for viewers who do not understand English. The song lyrics are in fact relevant for the plot, since Jane is influenced by their message and acts consequently. The result of this is that the Italian version has an additional L3, which coincides with L1.

Following the linguistic habits of second- and third-generation immigrants, Jane and Xiomara tend to choose English to communicate with both Anglophone and immigrant Hispanic people. This can be seen in Example 3, where Alba asks her granddaughter to think of five things that make her calm and whose first letters are those contained in the Spanish word calma. Jane, however, thinks of four things because she spells the word in English 
(calm), since this is the language which defines her identity as a Latina girl living in Miami. However, the Italian dubbed version is unable to preserve the metalinguistic comment made by Jane ("I spell it in English"), since the Italian word for "calm" is spelled the same as in Spanish (calma). By erasing Jane's statement about the language she wants to use, the Italian version fails to portray an important aspect of her identity and the way she perceives it. It can be noted that part-subtitles in Italian are missing here, as often happens in the second season of the Italian dubbed version.

Example 3. Chapter 30 (Season 2, Episode 8, 01.47)

\begin{tabular}{|c|c|}
\hline $\begin{array}{l}\text { ORIGINAL VERSION } \\
\text { [part-subtitles] }\end{array}$ & $\begin{array}{l}\text { ITALIAN DUBBING } \\
\text { (back translation) }\end{array}$ \\
\hline $\begin{array}{l}\text { Alba: Cuando algo te moleste, piensa en cosas } \\
\text { que te den calma. C-A-L-M-A. ¿Qué te hace } \\
\text { feliz que comience con la letra "C"? } \\
\text { [When you feel upset,/ } \\
\text { you need to think of } \\
\text { things that make you calm./ } \\
\text { C-A-L-M-A./ } \\
\text { Now, what's something } \\
\text { that makes you happy/ } \\
\text { that starts with the letter "C"?] } \\
\text { Jane: Cheese. } \\
\text { Alba: Y ahora con la letra "A". } \\
\text { [And now the letter "A."] } \\
\text { Jane: You, abuela. } \\
\text { Alba: iAy! ¿Y la "L"? } \\
\text { [And the "L?"] } \\
\text { Jane: Lists. And for "M", Mr. Monkey. } \\
\text { Alba: ¿Y la "A"? } \\
\text { Jane: No "A". I spell it in English! } \\
\text { Alba: Ok, entonces, calm. }\end{array}$ & $\begin{array}{l}\text { Alba: Cuando algo te moleste, } \\
\text { piensa en cosas que te den calma. } \\
\text { C-A-L-M-A. ¿Qué te hace feliz que } \\
\text { comience con la letra "C"? } \\
\text { Jane: Cheddar. } \\
\text { Alba: Y ahora con la letra "A". } \\
\text { Jane: Tú, abuela. (You, abuela) } \\
\text { Alba: ¡Ay! ¿Y la "L"? } \\
\text { Jane: Letterina. E con la "M", Mr. } \\
\text { Monkey. (Letter. And for "M", Mr. } \\
\text { Monkey.) } \\
\text { Alba: ¿Y la "A"? } \\
\text { Jane: No, la "A" l'ho già detta, } \\
\text { non ti ricordi? (No, I have } \\
\text { already mentioned "A", don't you } \\
\text { remember?) } \\
\text { Alba: Ok, entonces, calm. }\end{array}$ \\
\hline
\end{tabular}

Interestingly, Xiomara, who has never given up her dream of becoming a famous singer, always sings in Spanish. This spontaneous linguistic choice reveals an important aspect of her identity and expresses her deeply-felt connection to her heritage. Despite considering herself a U.S. citizen, when she sings she perceives herself as Latina. This symbolic relevance of language is preserved in the Italian version, in which Xiomara's songs are left unchanged $(\mathrm{L} 3 \mathrm{ST}=\mathrm{L} 3 \mathrm{TT})$.

A frequent multilingual discourse practice used by second- and third- generation Hispanic immigrants is code-mixing: the occasional or even frequent use of Spanish words and expressions in an English sentence may indicate 
a sense of shared identity or solidarity with the other speaker. Code-mixing occurs in relation to Hispanic cultural traditions, typical food (e.g. arepas, tres leches), vocatives - especially kinship terms - and greetings (e.g. hola). Jane always addresses her grandmother using the Spanish kinship term abuela, which bears important sociocultural and emotional connotations, expressing her respect for the Hispanic culture, and this is always maintained in the dubbed version. Jane does not consider herself perfectly bilingual: indeed, she explicitly states her difficulty in expressing certain concepts in Spanish (Example 4).

Example 4. Chapter 1 (Season 1, Episode 1, 29.40)

\begin{tabular}{|c|c|}
\hline $\begin{array}{l}\text { ORIGINAL VERSION } \\
\text { [part-subtitles] }\end{array}$ & $\begin{array}{l}\text { ITALIAN DUBBING (back translation) } \\
\text { [part-subtitles] }\end{array}$ \\
\hline $\begin{array}{l}\text { Alba: Me has roto el corazón. } \\
\text { [You've broken my heart.] } \\
\text { Jane: Oh, abuela, it is not what you } \\
\text { think. } \\
\text { Alba: Yo creo que tú me has estado } \\
\text { mintiendo por mucho tiempo. } \\
\text { [I think you have lied to me } \\
\text { for a very long time.] } \\
\text { Jane: No, I didn't, I... I got } \\
\text { accidentally... Oh, I don't even know } \\
\text { how to say this in Spanish! }\end{array}$ & $\begin{array}{l}\text { Alba: Me has roto el corazón. } \\
\text { [Mi hai spezzato il cuore.] } \\
\text { Jane: Oh, abuela, non è come credi. (Oh, } \\
\text { abuela, it is not how you think.) } \\
\text { Alba: Yo creo que tú me has estado mintiendo } \\
\text { por mucho tiempo. } \\
\text { [Credo che tu mi abbia mentito } \\
\text { per tantissimo tempo.] } \\
\text { Jane: No, non è vero... è... è stato... un } \\
\text { incidente... e... Oh non so come si dice in } \\
\text { spagnolo! (No, it's not true... it... it was... an } \\
\text { accident... and... Oh, I don’t even know how } \\
\text { to say this in Spanish!) }\end{array}$ \\
\hline
\end{tabular}

While greetings and vocatives in L3 are always preserved in the Italian version, when the L3 word or expression refers to cultural traditions, it is often translated into Italian, thus wiping out the multilingual nature of the utterance and its connotations. A key example of this is when Xiomara and Jane find out that the latter is pregnant. As Jane is still a virgin, they are both extremely shocked. Xiomara exclaims that her daughter is inmaculada, referring to the Immaculate Conception. Nevertheless, the dubbed version does not preserve code-mixing in this case and translates the entire line into L2 (immacolata), thus partly losing the cultural connotation embedded in the Spanish expression and producing a loss in terms of transcultural transmission (Example 5). 
Example 5. Chapter 1 (season 1, episode 1, 16.09)

\begin{tabular}{|l|l|}
\hline \multicolumn{1}{|c|}{ ORIGINAL VERSION } & \multicolumn{1}{|c|}{ ITALIAN DUBBING (back translation) } \\
\hline Doctor: Pink means pregnant. & Doctor: Rosa vuol dire incinta. (Pink means \\
Jane: But I've never had sex! & pregnant.) \\
Xiomara: Inmaculada! You are & Jane: Ma non ho mai fatto sesso! (But I've never \\
inmaculada! & had sex!) \\
Jane: What? No, Mom. & $\begin{array}{l}\text { Xiomara: Immacolata! Tu sei l'immacolata! } \\
\text { (Immaculate! You're the Immaculate Conception!) } \\
\\
\text { Jane: Cosa? No, mamma. (What? No, Mom.) }\end{array}$ \\
\hline
\end{tabular}

Code-switching in JTV is occasionally used by bilingual characters to create social boundaries and exclude other speakers from a conversation. When Jane brings home her new boyfriend Rafael and introduces him to Xiomara and Alba, her mother makes a comment in Spanish, thinking that Rafael will not understand (Example 6). Surprisingly, not only does Rafael understand but he also replies in Spanish. L3 is maintained (L3ST = L3TT) in the Italian dubbing and part-subtitles are provided in both versions.

Example 6. Chapter 11 (Season 1, Episode 11, 14.25)

\begin{tabular}{|c|c|}
\hline $\begin{array}{l}\text { ORIGINAL VERSION } \\
\text { [part-subtitles] }\end{array}$ & $\begin{array}{l}\text { ITALIAN DUBBING } \\
\text { [part-subtitles] }\end{array}$ \\
\hline $\begin{array}{l}\text { Rafael: As I was saying, I believe } \\
\text { that hard work is the key to } \\
\text { success. I mean, as a Taurus, } \\
\text { you must know what I mean. } \\
\text { Persistence is everything. } \\
\text { Xiomara: Lo preparaste bien, no } \\
\text { soy tonta. } \\
\text { [You've prepped him well. } \\
\text { I'm not a fool.] } \\
\text { Rafael: Claro que no es tonta. } \\
\text { [Of course you're not a fool.] }\end{array}$ & $\begin{array}{l}\text { Rafael: Quello che stavo dicendo, è che serve } \\
\text { lavorare sodo per avere successo. Voglio dire, } \\
\text { da buon toro lei lo sa bene. La perseveranza è } \\
\text { quello che conta. (What I was saying is that you } \\
\text { need to work hard to achieve success. I mean, } \\
\text { as a Taurus, you must know. Persistence is what } \\
\text { matters.) } \\
\text { Xiomara: Lo preparaste bien, no soy tonta. } \\
\text { [Lhai preparato per bene. } \\
\text { Non sono scema.] } \\
\text { Rafael: Claro que no es tonta. } \\
\text { [Certo che non è scema.] }\end{array}$ \\
\hline
\end{tabular}

Jane and Xiomara often play the role of interpreters, in particular when Alba speaks Spanish to non-Hispanic characters, such as Jane's first boyfriend, Michael. In Example 7 below, Jane translates her grandmother's words for Michael. In this case, a double translation is provided, since part-subtitles translate Alba's words in both versions, and, immediately afterwards, Jane gives her own diegetic translation into L1 and L2. 
Example 7. Chapter 2 (Season 1, Episode 2, 02.32)

\begin{tabular}{|c|c|}
\hline $\begin{array}{l}\text { ORIGINAL VERSION } \\
\text { [part-subtitles] }\end{array}$ & $\begin{array}{l}\text { ITALIAN DUBBING (back translation) } \\
\text { [part-subtitles] }\end{array}$ \\
\hline $\begin{array}{l}\text { Alba: ¿Puedo decir sólo una cosa? } \\
\text { [Can I just say one thing?] } \\
\text { Jane: Yes, go ahead. } \\
\text { Alba: Deberías de quedarte con el } \\
\text { bebé. } \\
\text { [You should keep the baby.] } \\
\text { Jane: ¡Abuela! } \\
\text { Xiomara: Ma! } \\
\text { Alba: Es un país libre, yo puedo decir } \\
\text { lo que siento. } \\
\text { [It's a free country, } \\
\text { I can say how I feel--] } \\
\text { Michael: What did she say? } \\
\text { Jane: She said that I should keep the } \\
\text { baby! }\end{array}$ & $\begin{array}{l}\text { Alba: ¿Puedo decir sólo una cosa? } \\
\text { [Posso dire solo una cosa? ] } \\
\text { Jane: Certo, dì pure. (Of course, tell me.) } \\
\text { Alba: Deberías de quedarte con el bebé. } \\
\text { [Dovresti tenere il bambino.] } \\
\text { Jane: Abuela! } \\
\text { Xiomara: Mamma! (Mom!) } \\
\text { Alba: Es un país libre, yo puedo decir lo que } \\
\text { siento. } \\
\text { [Siamo in un paese libero, } \\
\text { posso dire quello che penso--] } \\
\text { Michael: Che cosa ha detto? (What did she } \\
\text { say?) } \\
\text { Jane: Che dovrei tenere il bambino! (That I } \\
\text { should keep the baby!) }\end{array}$ \\
\hline
\end{tabular}

There are also cases in which part-subtitles are absent in the original version, and diegetic interpreting becomes the only translation available to viewers (Example 8). Michael and Jane are watching a soap opera in Spanish on TV and he asks her to translate the actor's words. It is interesting to note that the Villanueva family always watch telenovelas in Spanish'; it is a kind of everyday activity that brings the three women together, erasing temporarily their generational, cultural and linguistic differences. Part-subtitles are not provided on these occasions unless they are fundamental to the plot.

Example 8. Chapter 6 (season 1, episode 6, 03.11)

\begin{tabular}{|c|c|}
\hline ORIGINAL VERSION & ITALIAN DUBBING (back translation) \\
\hline $\begin{array}{l}\text { Michael: So, what's the guy in } \\
\text { the bolero jacket saying now? } \\
\text { Jane: "From our first meeting... } \\
\text { I knew it was you. I just } \\
\text { knew." }\end{array}$ & $\begin{array}{l}\text { Michael: E che cosa sta dicendo il ragazzo con il } \\
\text { bolero adesso? (And what's the guy in the bolero } \\
\text { jacket saying now?) } \\
\text { Jane: "Sin dal nostro primo incontro, sapevo che eri } \\
\text { tu, lo sapevo e basta." ("From our first meeting, I } \\
\text { knew it was you. I just knew it.") }\end{array}$ \\
\hline
\end{tabular}

Another multilingual character in JTV is Rogelio de la Vega, a telenovela star - El Presidente, the male protagonist of the soap opera The Passions of Santos - and Jane's father, although he met her only when she was twenty-three.

8. The presence of a soap opera within the soap opera is a distinctive feature of JTV. 
Rogelio is very traditional and attached to the Latino culture, but at the same time he wants to be accepted by American society. (He even tries to produce an American adaptation of his telenovela). The ambivalent aspect of his identity is reflected in his use of language(s). Besides speaking English with a recognisable Spanish accent, he uses English-Spanish code-switching and code-mixing when speaking to Hispanic characters (Example 9). Alba and Rogelio's collective use of the we-code represents a conscious way of expressing their common cultural background and building a relationship of solidarity.

Example 9. Chapter 8 (Season 1, Episode 8, 37.42)

\begin{tabular}{|l|l|}
\hline \multicolumn{1}{|c|}{$\begin{array}{c}\text { ORIGINAL VERSION } \\
\text { [part-subtitles] }\end{array}$} & \multicolumn{1}{c|}{\begin{tabular}{c}
\multicolumn{1}{|c|}{ ITALIAN DUBBING } \\
[part-subtitles]
\end{tabular}} \\
\hline $\begin{array}{l}\text { Rogelio: Alba, tan hermosa como } \\
\text { siempre. }\end{array}$ & $\begin{array}{l}\text { Rogelio: Alba, tan hermosa como siempre. } \\
\text { Alba: Ay, Rogelio, tú me halagas, } \\
\text { pero me gusta. }\end{array}$ \\
$\begin{array}{l}\text { [- Alba, beautiful as ever. } \\
\text { - Rogelio, you flatter me, but I like, tú me halagas, pero me gusta. } \\
\text { it.] }\end{array}$ & - Rogelio, mi lusinghi, ma apprezzo.] \\
\hline
\end{tabular}

Rogelio is frequently shown acting in his soap opera, in which he always speaks Spanish. These scenes are always part-subtitled rather than dubbed as acting in Spanish is a fundamental aspect of his identity and characterisation.

Code-switching is also exploited in JTV to mark moments of emotional involvement or intimacy. A significant instance is when Michael, who has always been at a loss when other characters speak Spanish, unexpectedly recites his vows to Jane in Spanish during their wedding ceremony. In this case, turn-specific code-switching has a metaphorical value, symbolising a romantic gesture and expressing his wish to bridge the linguistic and cultural gap with Jane's family. L3 lines are maintained in the dubbed version. Partsubtitles are not provided in the original and the dubbed version, because Jane recites the same vows in $\mathrm{L} 1$ and $\mathrm{L} 2$ respectively, thus providing a diegetic translation. 
Example 10. Chapter 44 (Season 2, Episode 22, 25.27)

\begin{tabular}{|c|c|}
\hline & tion) \\
\hline $\begin{array}{l}\text { Michael, } \\
\text { romise to } \\
\text { times and } \\
\text { in health. } \\
\text { nour you } \\
\text { ife, or } \\
\text { te tomo } \\
\text { osa. } \\
\text { próspero }\end{array}$ & $\begin{array}{l}\text { endo te, Michael, come mio sposo. } \\
\text { serti fedele, nella gioia e nel dolore, } \\
\text { la malattia, e di amarti e onorarti } \\
\text { della mia vita, finché morte non ci } \\
\text { ke you, Michael, as my husband. } \\
\text { be faithful to you in joy and in } \\
\text { and in health and to love you and } \\
\text { ll the days of my life, until death } \\
\text { hael, te tomo a ti, Jane, como mi } \\
\text { serte fiel en lo próspero y en lo } \\
\text { ud y en la enfermedad, y respetarte } \\
\text { mi vida o hasta que la muerte nos }\end{array}$ \\
\hline
\end{tabular}

Another multilingual, but unseen, character in JTV is the omniscient narrator, whose voice is heard in every episode. Known as the Latin Lover Narrator, his voice-overs summarise previous episodes and continuously comment on the events, often accompanied by on-screen text to emphasise his statements and create comic or ironic effects. Furthermore, he provides translations for the lines in Spanish (or other L3), and occasionally explains the meaning of specific words or expressions in L3 used by other characters or himself (Example 11).

Example 11. Chapter 6 (season 1, episode 6, 01.38)

\begin{tabular}{|l|l|}
\hline \multicolumn{1}{|c|}{ ORIGINAL VERSION } & \multicolumn{1}{|c|}{ ITALIAN DUBBING (back translation) } \\
\hline $\begin{array}{l}\text { Narrator: In novelas, this } \\
\text { is known as encuentro } \\
\text { significativo, or a "significant } \\
\text { encounter". }\end{array}$ & $\begin{array}{l}\text { Narrator: Nelle telenovelas, questo si chiama encuentro } \\
\text { significativo, cioè "incontro significativo". (In } \\
\text { telenovelas, this is known as encuentro significativo, or } \\
\text { "significant encounter".) }\end{array}$ \\
\hline
\end{tabular}

The narrator speaks English with a Spanish accent and sometimes uses code-switching and code-mixing with Spanish (Example 12). In a recent interview, voice-over actor Anthony Mendez claimed that his main concern was to avoid any kind of stereotype, while at the same time making the audience hear a real connection with the Spanish language. ${ }^{9}$

9. "How The Narrator Of Jane The Virgin Found His Voice". Online version: <http:// www.npr.org/sections/codeswitch/2016/05/16/477737210/how-the-narrator-of-janethe-virgin-found-his-voices 
Example 12. Chapter 4 (Season 1, Episode 4, 00.01)

\begin{tabular}{|c|l|}
\hline \multicolumn{1}{|c|}{ ORIGINAL VERSION } & \multicolumn{1}{|c|}{ ITALIAN DUBBING (back translation) } \\
\hline Narrator: Hola, it's me again! & $\begin{array}{l}\text { Narrator: Hola, rieccomi qui. (Hola, here I am } \\
\text { again!) }\end{array}$ \\
\hline
\end{tabular}

The narrator in the Italian dubbed version has lost any trace of Hispanic accent and speaks standard Italian. Furthermore, occurrences of code-mixing referring to Hispanic cultural traditions are lost. In Example 13, the cultural reference quinceañera, which in the Latino tradition is a girl's fifteenth birthday party, is rendered in Italian through an explanation, in order to make the target text accessible to the target viewers.

Example 13. Chapter 2 (Season 1, Episode 2, 00.51)

\begin{tabular}{|l|l|}
\hline \multicolumn{1}{|c|}{ ORIGINAL VERSION } & \multicolumn{1}{c|}{ ITALIAN DUBBING (back translation) } \\
\hline $\begin{array}{l}\text { Narrator: Jane's quinceañera was, } \\
\text { without a doubt, the worst party } \\
\text { she'd ever been to. }\end{array}$ & $\begin{array}{l}\text { Narrator: La festa dei quindici anni di Jane fu } \\
\text { senza dubbio la festa peggiore a cui lei abbia } \\
\text { mai partecipato. (Jane's fifteenth birthday party } \\
\text { was, without a doubt, the worst party she'd } \\
\text { ever been to.) }\end{array}$ \\
\hline
\end{tabular}

Rogelio's Spanish accent is preserved in the dubbed version, but a different strategy is applied for the translation of the narrator's speech. This difference may be due to the polysemiotic nature of the audiovisual text (Zabalbeascoa 2012): the character of Rogelio is visibly connected to the Hispanic culture, through his physical appearance, clothes and objects, while the narrator is literally invisible.

\subsection{Linguistic diversity in the original and Italian dubbed versions of Jane the Virgin}

Although JTV includes a significant amount of dialogue in Spanish, which mirrors the cross-cultural environment in which it is set (i.e. Miami), other forms of L3 appear throughout the show, making JTV a truly multilingual TV series. Even more significantly, the presence of different languages on screen is emphasised through metalinguistic comments, which draw attention to multilingualism in different ways. Frequently, it is the narrator who acts as a translator-interpreter, helping the audience understand the content of lines in L3, sometimes with the help of on-screen text, as can be seen in Example 14 , or simply by giving indications concerning the language spoken. When Czech is spoken for the first time, the narrator explains to the audience that the 
characters are speaking in that language (Example 15). This piece of information would not be directly deducible from the subtitles, which simply translate the content of the lines.

Example 14. Chapter 12 (Season 1, Episode 12, 15.35)

\begin{tabular}{|l|l|}
\hline \multicolumn{1}{|c|}{ ORIGINAL VERSION } & \multicolumn{1}{|c|}{ ITALIAN DUBBING } \\
\hline $\begin{array}{l}\text { KORUNA } \\
\text { A CZECH COIN }=4 / 10 \text { OF A } \\
\text { PENNY }\end{array}$ & CORONA - MONETA CECA $=$ \\
\hline
\end{tabular}

Example 15. Chapter 4 (Season 1, Episode 4, 37.20)

\begin{tabular}{|l|l|}
\hline \multicolumn{1}{|c|}{ ORIGINAL VERSION } & \multicolumn{1}{|c|}{ ITALIAN DUBBING (back translation) } \\
\hline $\begin{array}{l}\text { Ivan (in Czech): [I hope you have } \\
\text { the money.] }\end{array}$ & $\begin{array}{l}\text { Ivan (in Czech): [Spero che tu abbia i soldi.] } \\
\text { Petra (in Czech): }\end{array}$ \\
$\begin{array}{l}\text { Petra (in Czech): } \\
\text { [I nearly got arrested for murder } \\
\text { because of you.] }\end{array}$ & $\begin{array}{l}\text { Narrator: Chi di voi conosce le lingue ci sarà } \\
\text { già arrivato: stanno parlando ceco. (Those of } \\
\text { amorator: I am sure that linguists } \\
\text { you who speak many languages have probably } \\
\text { but they are speaking Czech. }\end{array}$ \\
\hline
\end{tabular}

Czech appears quite regularly in JTV, since one of the main characters, Petra, comes from the Czech Republic. She fled her home country with her mother and moved to the U.S to escape her criminal ex-boyfriend. While Petra is perfectly capable of hiding her foreign accent and can speak English with an American accent, which reflects her ability to integrate into American society, her mother Magda and ex-boyfriend Milos do not even try to conceal their strong accent, signifying their attitude of resistance towards the English-speaking country. Their speech in English is characterised by non-standard grammatical and phonological features, such as the omission of articles and determiners and the systematic substitution of the voiced labiovelar approximant sound /w/ with the voiced labiodental fricative /v/. Example 16 shows an exchange between Petra and Milos, in which he resorts to code-mixing because he cannot find the words in English. The Italian dubbing maintains the code-mixing as well as Milos's foreign accent, which is over-emphasised as a compensation strategy, because the non-standard grammar is normalised. 
Example 16. Chapter 12 (Season 1, Episode 12, 15.23)

\begin{tabular}{|c|c|}
\hline ORIGINAL VERSION & ITALIAN DUBBING (back translation) \\
\hline $\begin{array}{l}\text { Milos: I understand you are } \\
\text { upset with me. }\end{array}$ & $\begin{array}{l}\text { Milos: Capisco che sei arrabbiata con me. (I understand } \\
\text { you are angry with me.) }\end{array}$ \\
\hline Petra: You threw acid at me. & Petra: Mi hai tirato dell'acido. (You threw acid at me.) \\
\hline Milos: At your mother. & Milos: A tua madre. (At your mother.) \\
\hline $\begin{array}{l}\text { Petra: It hit my mother, only } \\
\text { because I bent over to pick } \\
\text { up a koruna. }\end{array}$ & $\begin{array}{l}\text { Petra: Ha colpito mia madre, perché mi sono piegata } \\
\text { a raccogliere una koruna. (It hit my mother, because I } \\
\text { bent over to pick up a koruna.) }\end{array}$ \\
\hline $\begin{array}{l}\text { Milos: That moment was } \\
\text { very low point for me. }\end{array}$ & $\begin{array}{l}\text { Milos: Quel momento è stato uno dei peggiori della mia } \\
\text { vita. (That was one of the worst moments in my life.) }\end{array}$ \\
\hline $\begin{array}{l}\text { Petra: For my mother too. } \\
\text { Milos: Listen. Instead }\end{array}$ & $\begin{array}{l}\text { Petra: Lo è stato anche per mia madre. (For my mother } \\
\text { too.) }\end{array}$ \\
\hline of jail they sent me to & Milos: Invece che in galera mi hanno spedito in un \\
\hline rehabilitation programme. & programma di riabilitazione, non so come si dice qui... \\
\hline $\begin{array}{l}\text { I don't know how to say in } \\
\text { English... (in Czech) [... }\end{array}$ & $\begin{array}{l}\text { (in Czech) }[\ldots \text { gestione della rabbia]. } \\
\text { (Instead of jail they sent me to a rehabilitation }\end{array}$ \\
\hline anger management] & programme. I don't know how they say it here...) \\
\hline
\end{tabular}

However, the same strategy is not applied to translating Magda's speech. She speaks standard Italian with no particular accent, which becomes problematic when her deviant pronunciation leads to misunderstandings with other characters. A key scene is when Jane cannot understand Magda because the latter is unable to utter the phoneme /w/, which does not exist in Czech, and substitutes it with the sound $/ \mathrm{v} /$, so that the words 'wary' and 'very' are pronounced as homophones (Example 17). The Italian version presents a case of translation loss, since the same kind of misunderstanding based on phonology cannot be reproduced. A strategy of adaptation is applied. In the dubbed version, the misunderstanding is based on the similarity between the adjective diffidente (suspicious) and the phrase difendi dente (defend tooth), which Magda confuses in her speech. However, since Magda speaks standard Italian, the scene is not as credible as the original one and does not recreate the same humorous effect. Italian viewers are given a different portrayal of this character, who is presented as more integrated linguistically into the host society. 
Example 17. Chapter 27 (Season 2, Episode 5, 24.37)

\begin{tabular}{|c|c|}
\hline ORIGINAL VERSION & ITALIAN DUBBING (back translation) \\
\hline $\begin{array}{l}\text { Magda: Milos is internet } \\
\text { criminal. You should be } \\
\text { very wary. } \\
\text { Jane: Very very what? } \\
\text { Magda: Very wary, not } \\
\text { very very! } \\
\text { Jane: I'm still not } \\
\text { following. } \\
\text { Magda: Very wary! } \\
\text { Jane: Oh, very wary. } \\
\text { Magda: That's what I said, } \\
\text { very wary. }\end{array}$ & $\begin{array}{l}\text { Magda: Milos è un criminale informatico. Meglio se } \\
\text { difendi dente. (Milos is an internet criminal. It is better if } \\
\text { you defend tooth.) } \\
\text { Jane: È un messaggio in codice? (Is that a coded } \\
\text { message?) } \\
\text { Magda: Difendi dente, non difendi il dente! (Defend } \\
\text { tooth, not defend your tooth!) } \\
\text { Jane: Non capisco che vuol dire. (I don't understand what } \\
\text { you mean.) } \\
\text { Magda: Difendi dente! (Defend tooth!) } \\
\text { Jane: Oh, intende diffidente. (Oh, you mean suspiscious.) } \\
\text { Magda: È quello che ho detto, difendi dente! (That's what } \\
\text { I said, defend tooth!) }\end{array}$ \\
\hline
\end{tabular}

Furthermore, in the original version, on-screen text is occasionally used to highlight Magda's disjunctive pronunciation, through a transcription that is left unchanged in the dubbed version, thus depriving the viewers of an explanation in L2 (Example 18).

Example 18. Chapter 27 (Season 2, Episode 5, 23.31)

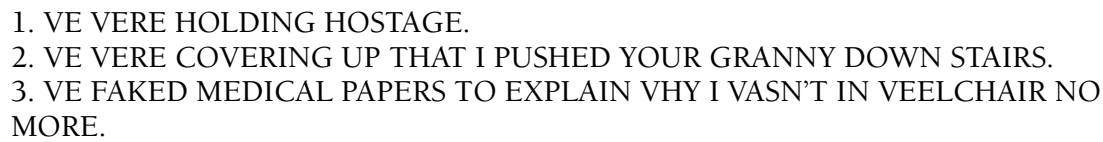

What emerges from the analysis is that JTV exploits multilingualism for different aims, namely realism, character portrayal (sociocultural characterisation) and humour. In addition, it leads the viewers' attention to the presence of different languages and accents through the use of oral and written metalinguistic comments, diegetic interpreting and part-subtitles.

The Italian dubbed version of JTV preserves linguistic diversity. However, it presents some inconsistencies which lead to a different characterisation, as in the case of the Czech characters. Furthermore, there is an important discrepancy between the use of part-subtitles in the first and second seasons of the show. While the first season includes subtitles in L2 whenever they appear in the original version, in the second season part-subtitles for the exchanges in L3 appear only in some episodes. However, it should be noted that the narrator often intervenes and his explanatory comments assist the audience in their understanding. As can be observed in Example 19, entire lines in L3 
(German) are left untranslated in the Italian version, but comprehension of the scene is nonetheless ensured by the narrator's voice-over.

Example 19. Chapter 25 (Season 2, Episode 3, 40.04)

\begin{tabular}{|l|l|}
\hline \multicolumn{1}{|c|}{ ORIGINAL VERSION } & \multicolumn{1}{|c|}{ ITALIAN DUBBING (back translation) } \\
\hline $\begin{array}{l}\text { Man: Sie ist absolut unausstehlich. Und } \\
\text { Rose weiß noch nicht mal dass sie weg }\end{array}$ & $\begin{array}{l}\text { Man: Sie ist absolut unausstehlich. Und Rose } \\
\text { ist. }\end{array}$ \\
weiß noch nicht mal dass sie weg ist. \\
Luisa: Rose? Ho sentito Rose. (Rose? I heard \\
And Rose hasn't even & Rose.) \\
noticed she's gone.] & Man: Wir müssen ein starkeres Signal \\
Luisa: Rose? I heard Rose. & senden. \\
Man: Wisa: Vuole una mia foto per caso? Mi \\
senden. & offendete. Avete un rossetto? (Does she \\
[We have to send a stronger message.] & wants a picture of me? You're offending me. \\
Luisa: She wants a picture of me? She's & Do you have a lipstick?) \\
outrageous. Do you have any lipstick? & di far capire a Rose che Luisa è scomparsa, \\
Narrator: Wait a minute. If they're & allora non è stata Rose a rapirla! (Wait \\
trying to get Rose to notice Luisa's & a moment. If they're trying to help Rose \\
missing... then Rose isn't the one who & understand that Luisa's missing... then Rose \\
had her kidnapped! & isn't the one who kidnapped her!) \\
Luisa: No, wait, no... you can't... you & Luisa: Oh, aspettate... non potete... farmi \\
can't hurt me... & male. (No, wait... you can't... you can't hurt \\
Narrator: Which means Luisa is not so & me...) \\
safe here after all. & Narrator: Quindi Luisa non è affatto al \\
Man: Nachricht gesendet. & sicuro. (So Luisa is not so safe at all.) \\
[Message sent.] & Man: Nachricht gesendet. \\
\hline
\end{tabular}

\section{Conclusions}

Multilingual TV series are today appearing increasingly frequently, contributing to the dissemination of linguistic diversity and presenting viewers with a wide range of language contacts and uses. Together with multilingual films, multilingual TV series show that language is a fundamental aspect of characterisation: characters present themselves through language and use language to build their identity.

The analysis of the first two seasons of JTV in its original and Italian dubbed versions confirms that multilingualism has become a key element in TV series as well as an increasingly important issue in AVT. Recent studies on the translation of multilingual films for Italian audiences (Beseghi 2017; Bonsignori \& Bruti 2014; De Bonis 2014, 2015; Monti 2014, 2016; Minutella 2012) have underlined the fact that dubbing professionals are gradually paying more attention to multilingualism and trying to reproduce it in the target version by way of a combination of translation strategies. This tendency also emerges clearly from 
the analysis of the translated version of JTV, a TV series where multilingualism is pervasive, multi-faceted and full of cross-cultural connotations.

This investigation finds that the Italian translators attempt to maintain code-switching as much as possible, preserving on the whole the multilingual nature of the audiovisual text. Overall, the instances of turn-specific code-switching are maintained in the dubbed version, thus respecting the multilingual setting and the immigrant characters' multicultural identities, and carrying over the functions of code-switching into the original version. What stands out in the Italian version, however, is a different approach to the use of part-subtitling, which is present in the first season and partially absent in the second. This non-translation strategy is unusual in a dubbing country such as Italy, and it alters the nature of the original text, which translates the dialogues in L3 through open subtitles into L1.

A variety of strategies are used in translating code-mixing. It is always maintained in the case of greetings and vocatives, but sometimes rendered through explicitation in the case of culture-specific words or cultural references. This leads to L3 invisibility, and to the transposition of language varieties and accents, which are not always reproduced in the target text. Multicultural identities and transcultural connotations are thus partially obscured. In fact, while Spanish, Czech and German are preserved in the Italian version, intralingual variation is rendered in different ways, which may also result in a change of connotation or in different character portrayal. To deal with intralingual variation, translators follow more than one strategy, ranging from hypercharacterisation to lack of characterisation of the target language, and the strategies seem to vary according to the character speaking. For example, foreign accents are in some cases overemphasised (i.e. Alba, Milos), in others maintained (i.e. Rogelio) and in others neutralised (i.e. the Narrator, Magda).

It can be concluded that the overall approach in the Italian dubbing of JTV is to maintain the presence of $\mathrm{L} 3$ as much as possible. This seems to confirm the recent trend among AVT professionals to acknowledge the important role played by language(s) in filmic texts and to embrace hybrid approaches in order to deal with the complexity of multilingualism. However, some problematic issues remain, such as the rendering of different forms of intralingual variation and their complex functions, which are sometimes very challenging, if not impossible, to transfer to another language. Moreover, since TV series build serial diegetic universes with which viewers engage, AVT has the responsibility to recreate these universes for the target audience as coherently as possible, in terms of both language use and character portrayal. Further research is needed to investigate the different forms that multilingualism takes in the complex fictional world of the TV series and the new challenges it poses to AVT. 


\section{References}

BALDO, Michela. (2009) "Subtitling Multilingual Films. The Case of Lives of the Saints, an Italian-Canadian TV Screenplay.” In: Federici, Federico (ed.) 2009. Translating Regionalised Voices in Audiovisuals. Roma: Aracne, pp. 117-135.

BALDO, Michela. (2010) "Dubbing Multilingual Films: La Terra del Ritorno and the Italian Canadian Diaspora." Multimedialectranslation. inTRAlinea Special Issue. Electronic version: <http://www.intralinea.org/specials/article/ Dubbing_multilingual_films>

BARTOLL, Eduard. (2006) "Subtitling Multilingual Films." In: Carroll, Mary; Heidrun Gerzymisch-Arbogast \& Sandra Nauert (eds.) 2006. Proceedings of the Marie Curie Euroconferences MuTra: Audiovisual Translation Scenarios. Electronic version: <http://www.euroconferences.info/proceedings/2006_ Proceedings/2006_Bartoll_Eduard.pdf>

BESEGHI, Micòl. (2011) "Fenomeni Linguistici nella Rappresentazione delle Identità Diasporiche nel Film The Namesake." In: Bondi, Marina; Giovanna Buonanno; Cesare Giacobazzi \& Maria Donata Panforti (eds.) DiaLogos. Appartenenze Multiple: Prospettive Interdisciplinari su Immigrazione, Multiculturalismo, Esperienze Cross-culturali. Modena: Officina Edizioni, pp. 39-50.

BESEGHI, Micòl. (2017) Multilingual Films in Translation. A Sociolinguistic and Intercultural Study of Diasporic Films. Oxford: Peter Lang.

BLEICHENBACHER, Lukas. (2008) Multilingualism in the Movies. Hollywood Characters and Their Language Choices. Tübingen: Franke Verlag.

BONSIGNORI, Veronica \& Silvia BRUTI. (2014) "Representing Varieties of English in Film Language and Dubbing." In: Bollettieri Bosinelli, Rosa Maria; Elena Di Giovanni \& Linda Rossato (eds.) 2014. Across Screens Across Boundaries. Special Issue of inTRAlinea. Electronic version: <http://www.intralinea.org/specials/ article/representing_varieties_of_english_in_film_language_and_dubbing>

BRUTI, Silvia \& Elena Di Giovanni (eds.) (2012) Audiovisual Translation Across Europe: An Ever-changing Landscape. Oxford: Peter Lang.

CORRIUS, Montse \& Patrick ZABALBEASCOA. (2011) "Language Variation in Source Texts and their Translations: The Case of L3 in Film Translation." Target 23:1, pp. 113-130.

DE BONIS, Giuseppe. (2014) "Alfred Hitchcock Presents: Multilingualism as a Vehicle for ... Suspense. The Italian Dubbing of Hitchcock's Multilingual Films." Linguistica Antverpiensia, New Series. Themes in Translation Studies 13, pp. 169-92.

DE BONIS, Giuseppe. (2015) "Translating Multilingualism in Film: A Case Study on Le concert." New Voices in Translation Studies 12, pp. 50-71.

DE Higes-Andino, Irene. (2014) "The Translation of Multilingual Films: Modes, Strategies, Constraints and Manipulation in the Spanish Translations of It's 
a Free World..." Linguistica Antverpiensia, New Series Themes in Translation Studies 13, pp. 211-231.

De Higes-Andino, Irene; Ana María Prats-Rodríguez; Juan José MartínezSierra \& Frederic Chaume. (2013) "Subtitling Language Diversity in Spanish Immigration Films." Meta 58:1, pp. 134-145.

DelabastiTA, Dirk. (2002) "A Great Feast of Languages: Shakespeare's Bilingual Comedy in King Henry V and the French Translators." The Translator 8:2, pp. 303-340.

DelabastiTA, Dirk. (2009) "Fictional Representations." In: Baker, Mona \& Gabriela Saldanha (eds.) 2009. Routledge Encyclopedia of Translation Studies. London: Routledge, pp. 109-112.

DíAZ-CINTAS, Jorge. (2011) "Dealing with Multilingual Films in Audiovisual Translation." In: Wolfang Pöckl, Ingeborg Ohnheiser, and Peter Sandrini, (eds.) 2011. Translation Sprachvariation Mehrsprachigkeit. Frankfurt am Main: Peter Lang, pp. 215-233.

GRUTMAN, Rainier. (1996) "Langues Étrangères et Savoir Romantique: considérations préliminaires.” TTR: Traduction-Terminologie-Rédaction 9:1, pp. 71-90.

GumPERZ, John. (1982) Discourse Strategies. Cambridge: Cambridge University Press.

HEISS, Christine. (2004) "Dubbing Multilingual Films: A New Challenge?" Meta 49:1, pp. 208-220.

INNOCENTI, Veronica \& Guglielmo PeSCATORE. (2014) "Changing series: Narrative models and the role of the viewer in contemporary television seriality." Between 4:8, pp. 1-15.

Kozloff, Sarah. (2000) Overhearing Film Dialogue. Berkeley: University of California Press.

MeYlaerTS, Reine. (2006) "Heterolingualism in/and Translation: How Legitimate are the Other and His/Her Language? An Introduction." In: Meylaerts, Reine (ed.) 2006. Heterolingualism in/and Translation, Special issue of Target 18:1, pp. 1-15.

MinUtella, Vincenza. (2012) "You Fancying Your Gora Coach is Okay with Me: Translating Multilingual Films for an Italian Audience." In: Remael, Aline; Pilar Orero \& Mary Carrol (eds.) 2012. Audiovisual Translation and Media Accessibility at the Crossroads. Amsterdam: Rodopi, pp. 313-334.

MonTI, Silvia. (2014) "Code-switching in British and American Films and Their Italian Dubbed Version." Linguistica Antverpiensia, New Series, Themes in Translation Studies 13, pp. 135-168.

MonTI, Silvia. (2016) "Reconstructing, Reinterpreting and Renarrating Codeswitching in the Italian Dubbed Version of British and American Multilingual films.” In: Díaz Cintas, Jorge, Ilaria Parini \& Irene Ranzato (eds.) 2016. 
Ideological Manipulation in Audiovisual Translation, Special issue of Altre Modernità, pp. 68- 91.

MYers-SCotton, Carol. (1997) Duelling Languages: Grammatical Structure in Codeswitching. Oxford: Oxford University Press.

O'Sullivan, Carol. (2007) "Multilingualism at the Multiplex: a New Audience for Screen Translation?" In: Remael, Aline \& Josélia Neves (eds.) 2007. A Tool for Social Integration? Audiovisual Translation from Different Angles, Linguistica Antverpiensia, New Series, Themes in Translation Studies 6, pp. 81-95.

O'Sullivan, Carol. (2011) Translating Popular Film. Houndmills: Palgrave Macmillan.

PARINI, Ilaria. (2009) "The transposition of Italian American in Italian dubbing." In:

Federici, Federico (ed.) 2009. Translating Regionalised Voices for Audiovisuals. Roma: Aracne, pp.157-178.

PARINI, Ilaria. (2015) "Cultural and linguistic issues at play in the management of multilingual films in dubbing" in Lukasz Bogucki and Mikolaj Deckert (eds.) 2015. Accessing Audiovisual Translation. Bern: Peter Lang, pp. 27-50.

RANZATO, Irene. (2015) Translating Culture Specific References on Television: The Case of Dubbing. London \& New York: Routledge.

SCAGLIONI, Massimo. (2006) TV di culto: La serialità televisiva americana e il suo fandom. Milano: Vita \& Pensiero.

Voellmer, Elena \& Patrick ZabalbeascoA. (2014) "How Multilingual Can a Dubbed Film Be? Language Combinations and National Traditions as Determining Factors." Linguistica Antverpiensia, New series. Themes in translation studies 13, pp. 232-250.

WaHL, Chris. (2005) "Discovering a Genre: the Polyglot Film." Cinemascope Independent Film Journal 1. Electronic version: <cinema-scope.com>

WaHL, Chris. (2008) "Du Deutscher, Toi Français, You English: Beautiful! - The Polyglot Film as a Genre." In: Christensen, Miyase \& Nezih Erdoğan (eds.) 2008. Shifting Landscapes. Film and Media in European Context. Newcastle: Cambridge Scholars Publishing, pp. 334-350.

Wardhaugh, Ronald. (2002) An Introduction to Sociolinguistics (4th edition). Oxford: Blackwell.

ZABALBEASCOA, Patrick \& Montse CoRRIUS. (2012) "How Spanish in American Film is Rendered in Translation. Dubbing Butch Cassidy and the Sundance Kid in Spain." Perspectives: Studies in Translatology 20:3, pp. 1-16.

ZabAlBEASCOA, Patrick. (2012) "Translating Dialogues in Audiovisual Fiction." In: Brumme, Jenny \& Anna Espunya (eds.) 2012. The Translation of Fictive Dialogue. Amsterdam \& New York: Rodopi, pp. 63-78. 


\section{Filmography}

Breaking Bad (AMC 2008-2013)

Devious Maids (ABC 2013-2016)

Fresh Off the Boat (ABC 2015- )

Game of Thrones (HBO 2011- )

Heroes (NBC 2006-2010)

Hinterland (BBC 2014-2016)

Jane the Virgin (CBS 2014- )

Juana la Virgen (RCTV 2002)

Lost (ABC 2004-2010)

Missing, The (BBC 2014- )

Narcos (Netflix 2015- )

Orphan Black (Space 2013-2017)

Orange is the New Black (Netflix 2013- )

Outlander (Starz 2014- )

Prison Break (20 ${ }^{\text {th }}$ Century Fox 2005- )

\section{BIONOTE / BIOGRAFIA}

Micòl BeSEGH holds a PhD in Comparative Languages and Cultures from the University of Modena and Reggio Emilia and teaches English Language and Translation at the University of Parma. Her main research interests and publications concern the fields of audiovisual translation (multilingualism and linguistic variation in audiovisual texts, the transposition of orality in subtitling, AVT as a pedagogic tool in language teaching and the phenomenon of fansubbing), the didactics of translation, corpus linguistics and learner autonomy in foreign language education.

MICÒL BESEGHI è dottore di ricerca in Lingue e Culture Comparate (Università di Modena e Reggio Emilia) e insegna Lingua e Traduzione Inglese presso l'Università di Parma. I suoi principali interessi di ricerca e pubblicazioni riguardano la traduzione audiovisiva (il multilinguismo e la variazione linguistica nei testi audiovisivi, la trasposizione dell'oralità nei sottotitoli, la traduzione audioviosiva come strumento didattico nell'insegnamento della lingua e il fenomeno del fansubbing), la didattica della traduzione, la linguistica dei corpora e l'autonomia nell'apprendimento della lingua. 